\title{
Diel vertical migration and life strategies of two phytal- dwelling harpacticoids, Ambunguipes rufocincta and Eudactylops spectabilis
}

\author{
SHINJI SHIMOde ${ }^{1 *} \&$ YoshihISA ShiraYAMA ${ }^{2}$ \\ ${ }^{1}$ Graduate School of Environmental and Information Sciences, Yokohama National University, 79-2 Tokiwadai, Hodogaya, \\ Yokohama, 240-8501, Japan \\ ${ }^{2}$ Seto Marine Biological Laboratory, Graduate School of Sciences, Kyoto University, 459 Shirahama, Nishimuro, Wakayama, \\ 649-2211, Japan
}

Received 5 August 2005; Accepted 15 November 2005

\begin{abstract}
Seasonal occurrence, diel vertical migration (DVM), biomass (dry weight, carbon and nitrogen contents), growth and behavior of the two phytal-dwelling harpacticoid copepods, Ambunguipes rufocincta and Eudactylops spectabilis, were investigated using field samplings and laboratory experiments. The field samplings were conducted at a subtidal station (St. M; ca. $6.5 \mathrm{~m}$ depth) in Tanabe Bay, Japan from March 1999 to January 2000. The results from the field revealed that the two species performed DVM between the water column and macroalgal beds of Colpomenia sinuosa (brown algae), and the seasonal occurrence of the two species at St. M were almost identical to that of $C$. sinuosa, which bloomed only between December and May. The carbon/nitrogen ratios of A. rufocincta (5.00 \pm 0.60$)$ and E. spectabilis $(3.95 \pm 0.66)$ differed, probably due to the differences in their foods. Laboratory incubation showed that $E$. spectabilis needed both $C$. sinuosa and sediments as food for growth, whereas A. rufocincta that was fed only with the macroalgae was able to grow to maturity. Our results suggested that their DVM behaviors of both species were related to the dispersal of copepodids and adults, because 1) the nauplii grew on $C$. sinuosa, 2) their main food items were $C$. sinuosa and sediments, and 3) mating might not be the main purpose of the DVM since females with egg sacs emerged into the water column. Moreover, in later field investigations during summer, refuge populations of $A$. rufocincta were collected from the seagrass Halophila ovalis in an area shallower than St. M, indicating that A. rufocincta might sustain its population by moving to different habitats though the DVM behavior and changing food items from $C$. sinuosa to $H$. ovalis during summer. Therefore, at least for A. rufocincta, the DVM behavior might be indispensable in their life strategy for sustaining their population year round.
\end{abstract}

Key words: phytal-dwelling harpacticoids, diel vertical migration, macroalgae, $\mathrm{C} / \mathrm{N}$ ratio

\section{Introduction}

Most marine harpacticoid copepods are benthic species, keeping contacts with sediment or macroalgae (or seagrass) in benthic environments. These benthic harpacticoids have been thought to play important roles from the points of view of production and biodiversity in meiobenthic communities (Hicks \& Coull 1983), because they usually numerically dominate the communities, after nematodes. Among the benthic harpacticoids inhabiting shallow waters, some species have been recognized as temporary plankton because they sometimes swim upward into the pelagic environment from their benthic habitats such as intertidal sedi-

\footnotetext{
*Corresponding author: Shinji Shimode; E-mail, shimode@ynu.ac.jp
}

ments (Armonies 1988, 1989, 1990), subtidal sand and seagrass (Walters \& Bell 1986, Walters 1988a, Kurdziel \& Bell 1992). Passive swimming behaviors have been observed when sediments with benthic animals are eroded by strong water currents (Armonies 1994), and this mainly occurs in intertidal zones of sandy shores or mud flats where strong tidal wave actions exist. In contrast, active swimming behaviors (Armonies 1994) have been observed in many marine benthic habitats, e.g., tropical coral reefs, temperate sand bottoms and seagrass (or macroalgal) beds. Most of these harpacticoids swim into the water column after sunset and back to their benthic habitats before sunrise, and this is referred to as diel vertical migration (DVM) between benthic and pelagic environments. Possible reasons for the DVM in each species are still not fully understood, 

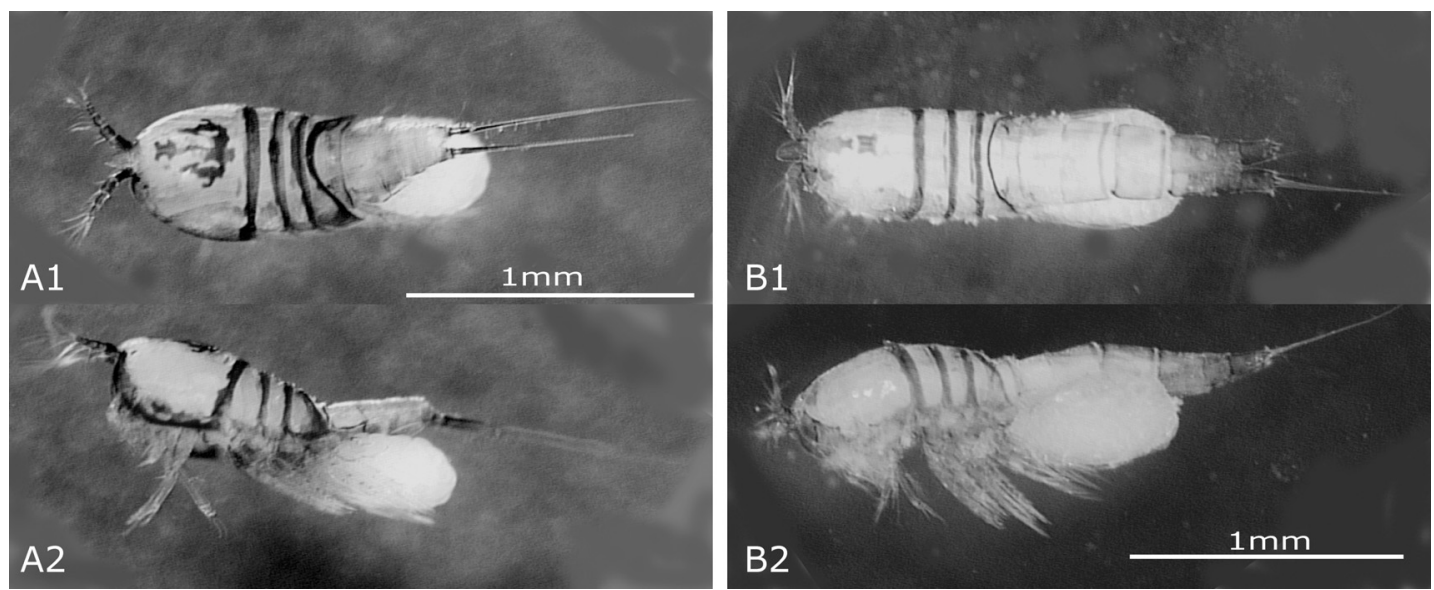

Fig. 1. Adult females of Ambunguipes rufocincta (A) and Eudactylops spectabilis (B). A1 and B1: dorsal views. A2 and B2: lateral views.

although they are thought to depend on their life history strategies, such as feeding, dispersal, mating and avoidance of predation (Walters \& Bell 1994). Moreover, in previous studies of active swimming harpacticoids, actual distributional patterns of the harpacticoids in the water columns were unclear, because emergence-traps and/or reentry-traps (Armonies 1994) were employed. Although these traps can catch animals actively swimming out of benthic habitats, they provide no information about the distributions of the animals in the water columns.

Ambunguipes rufocincta (Brady 1880) (family Ambunguipediidae; body length: female $=$ ca. $1.2 \mathrm{~mm}$, male $=\mathrm{ca}$. $1.0 \mathrm{~mm}$ ) and Eudactylops spectabilis (Brian 1923) (family Thalestridae; body length: female $=$ ca. $1.9 \mathrm{~mm}$, male $=$ ca . $1.5 \mathrm{~mm}$ ) are neritic harpacticoids (Fig. 1). The two species are considered to be phytal-dwelling species, because they have been collected from temperate benthic macroalgal habitats (Chang \& Song 1995, Song et al. 1999). We also collected these species in the water column in the shallow waters of Tanabe Bay, Japan (Shimode \& Shirayama 2004), which was the first record of the two species in Japan. During winter to spring, they occurred more abundantly than other harpacticoids at the sampling site (excluding holoplanktonic species), and their body sizes were larger than most planktonic copepod species collected at the site. In this study, we revealed the DVM of $A$. rufocincta and $E$. spectabilis from the field sampling data. In addition, using laboratory experiments and observations, their biomass (dry weight, carbon and nitrogen contents and body weightlength correlations), development (generation times) and behaviors (feeding ecology) were investigated. From these field and laboratory studies, the main advantages of their DVM were discussed.

\section{Materials and Methods}

\section{Study site}

Our sampling station (St. M) was located at sea off a sandy beach in the south part of Tanabe Bay (Fig. 2). There are no rivers around the beach and the mean depth of St. M was $6.5 \mathrm{~m}$. The bottom substratum of St. M consists primarily of sand and some gravel. Many patchy macroalgal mats of Colpomenia sinuosa (Phaeophyceae) grew during winter to spring. During the same periods, the mats of $C$. sinuosa were commonly observed at other beaches in the bay (e.g., Ezura Harbor, Hatake Isand, etc.). However, such large macrophytal mats were not observed during the rest of the year.

\section{Seasonal sampling and data analysis}

Sampling was carried out nine times from March 1999 to January 2000 at St. M. In each sampling series, samples were collected at ca. 3 hour intervals for 21 hours (i.e. eight times) following tidal cycles. At each time, samples were collected from four depth layers: surface, $2 \mathrm{~m}(1.5 \mathrm{~m}$ when the depth was shallower than $5 \mathrm{~m}$ ) below surface, $2 \mathrm{~m}$ above bottom and $0.2 \mathrm{~m}$ above bottom. To collected multi-layer samples, we used three different sampling devices. The sample series of March 1999 was collected with a hand diaphragm pump (500-H, The Bosworth). Seawater was pumped into a plankton net (125 $\mu \mathrm{m}$ mesh) on board to collect animals from each layer. The sampling volume of water was $0.02 \mathrm{~m}^{3}$ for each sample. A NIPR net (Nichiyu Giken Kogyo, which can filter seawater with an impeller pump attached in front of the net mouth in a stationary position) was used for the samplings on April 1999. The mesh size of the net was $100 \mu \mathrm{m}$ and a total of $0.48 \mathrm{~m}^{3}$ seawater was filtered from each layer. The sample series from May 1999 to January 2000 were collected with a submersible impeller pump (SX-150, Terada Pump). Seawater pumped from each layer was sieved in the same method as on March 1999 and 


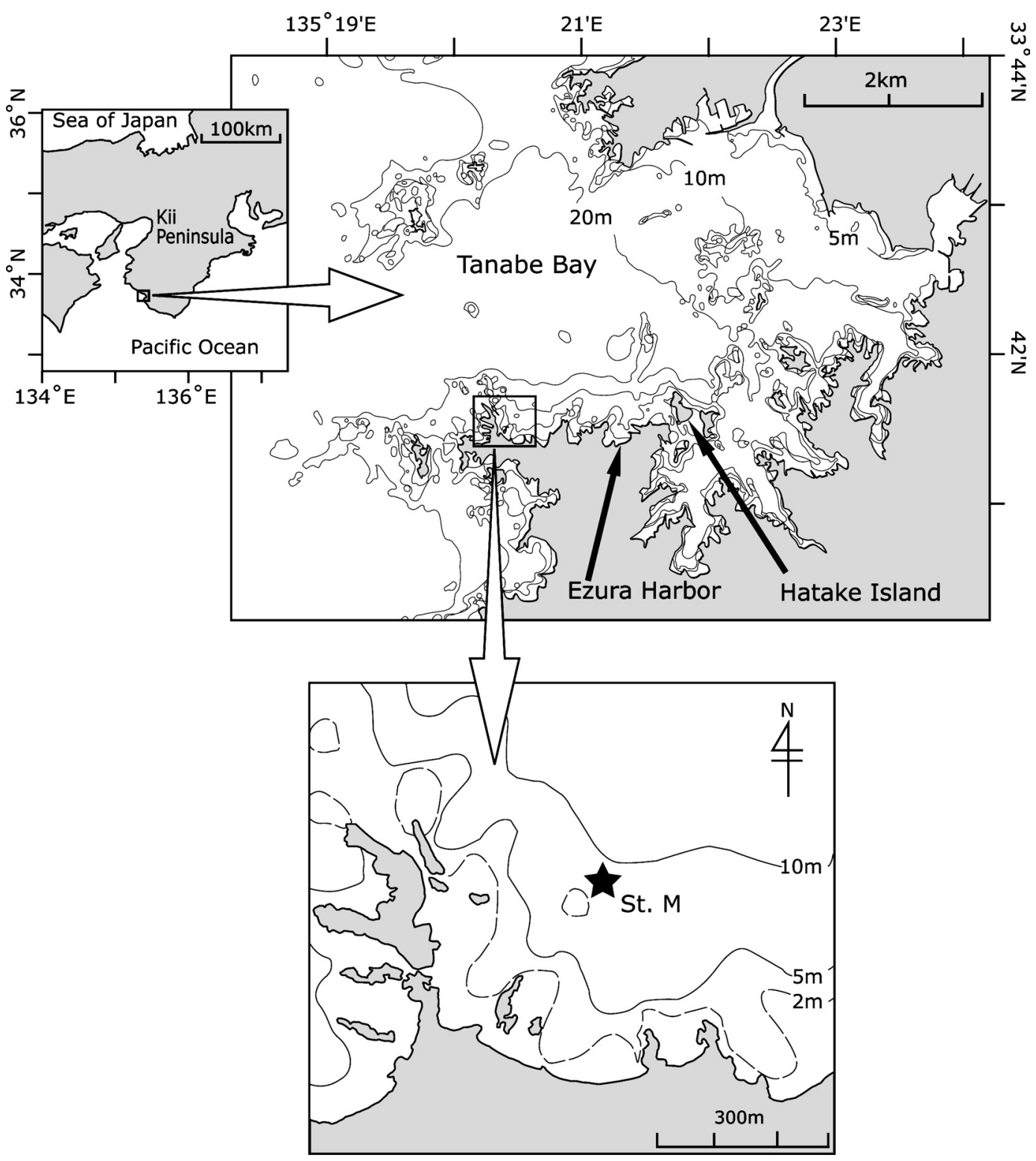

Fig. 2. Seasonal sampling station (St. M) and sampling sites of macrophytes (Ezura Harbor and Hatake Island) in Tanabe Bay, Japan.

the sample volume was $0.48 \mathrm{~m}^{3}$. Differences in the sampling efficiencies between the three sampling devices are thought to be negligible, since the faunal compositions of the samples were almost identical to those from simultaneous plankton-net samplings $(30 \mathrm{~cm}$ in diameter, $125 \mu \mathrm{m}$ mesh) (Shimode \& Shirayama 2004).

Prior to each plankton sampling, depth profiles of temperature, salinity and light quanta were recorded at $1 \mathrm{sec}$ intervals with temperature-depth, conductivity-temperature, and light quantum recorders (MDS-TD, MDS-CT and MDS-L, Alec Electronics). Depth profiles of dissolved oxygen (DO) at each sampling layer were also recorded using a DO meter (D-25, Horiba) during August 1999 to January 2000. A salinity refractometer (S/Mill-E, Atago) and an accessory thermometer of the DO meter were used for the sampling on September 1999 due to malfunctioning of the TD sensor. The seawater $(50 \mathrm{ml})$ from each sampling layer was filtered with a glass fiber filter (Whatman GF/C) for later determination of extracted (with $\mathrm{N}, \mathrm{N}$-dimethylformamide) chlorophyll $a$ concentration with a fluorometer (TD-700, Turner Designs).

All plankton samples were subsequently fixed and preserved in buffered $10 \%$ formalin seawater solution on board. These fixed samples were used for identification and enumeration of Ambunguipes rufocincta and Eudactylops spectabilis. Adult females and males of the two species were counted separately, whereas their copepodids were not counted into sexes and stages. The data for each sampling series was defined as day (sunrise to sunset) or night (sunset to sunrise) and variation in the abundances of the species 
among day/night in each month were examined using a Mann-Whitney U-test. A Spearman's rank correlation analysis was carried out to test the correlations among the abundances of each species and five environmental parameters (temperature, salinity, light quantum, DO and chl. $a$ ) in each sampling month.

Weighted mean depth (WMD), adopted from (Frost \& Bollens 1992), was used to examine DVM of $A$. rufocincta and $E$. spectabilis. The WMD was calculated as;

$$
W M D=\left(\sum n_{i} d_{i}\right) / \sum n_{i}
$$

where $n_{i}$ is abundance (individuals $\mathrm{m}^{-3}$ ) at depth $d_{i}$, taken to be the midpoint of each stratum at each sampling time.

\section{Sledge net sampling and laboratory incubation}

A sledge net $(30 \mathrm{~cm}$ width, $10 \mathrm{~cm}$ height and $330 \mu \mathrm{m}$ mesh) was used to collect samples of $A$. rufocincta and $E$. spectabilis for laboratory experiments and incubation. The samplings were carried out aboard the T/RV "Janthina III' at St. M and the samples were collected eight times between January and April 2001. All samplings were done during the daytime (10:00-12:00 hrs). Since the sledge net samples contained sediment and macroalgae, it was difficult to sort only animals from these primary samples. Hence, animals were rinsed from the primary samples with filtered seawater using a hand held plankton net (100 $\mu \mathrm{m}$ mesh). Individuals of $A$. rufocincta and E. spectabilis were subsequently sorted from these samples under a stereoscopic microscope.

Body length of each copepod individual was measured from the rostrum to the end of the caudal ramus using an ocular micrometer on a stereoscopic microscope. They were grouped into groups of 200-400 individuals by sex (only for adults) and size (for both adults and copepodids) in each species, depending on the number of individuals to attain the minimum dry weight of ca. $50 \mu \mathrm{g}$ necessary for further analyses. Each individual was cleaned with filtered seawater and subsequently rinsed with isotonic ammonium formate solution to remove salt, following the technique of Uye (1982). According to the groups, rinsed individuals were placed into pre-weighted tinfoil-boats for elemental analysis. The copepods on the tinfoil-boats were dried at $60^{\circ} \mathrm{C}$ for $48 \mathrm{hrs}$ using an oven dryer, and then their dry weights were measured using a microbalance (UMX2, Mettler Toledo), giving a precision of $0.1 \mu \mathrm{g}$. Weighted samples on tinfoil-boats were analyzed for total carbon and nitrogen using a $\mathrm{CN}$ analyzer (VarioES, Elementer).

The relationships between length (TL) and weight (W) of copepods were expressed as;

$$
W=a T L^{b}
$$

where $a$ and $b$ are constants. The data were transformed to logs of base 10, and liberalized as;

$$
\log W=\log a+b \log T L
$$

Ambunguipes rufocincta and E. spectabilisu were incubated in the laboratory to get individuals of early copepodid stages, because they were not effectively collected by the sledge due to the large mesh size. During this incubation, we also observed their behaviors and measured their developmental times. Adult females (including individuals with egg sacs) and males of the two species were sorted from sledge net samples for the incubation. After eggs of the two species hatched into nauplii in the laboratory incubation, they were subsequently incubated to copepodids, and used for the analysis of their dry weight, carbon and nitrogen contents and body weight-length correlations.

The incubation was performed in a thermo- and lightregulated incubator (BIOTRON NC-220S, NKsystem). These two species were incubated at $16^{\circ} \mathrm{C}$ and in $12: 12$ hours light/dark, which was similar to the field conditions of temperature and daylight cycles in February at St. M. Two different incubations of the species were carried out using two kinds of vessels, namely polycarbonate sample bottles ( 1 or $2 L$ ) and cell wells of polystyrene tissue culture plates (six-cells with a lid). The bottles were used for incubation of mass individuals (10-30 individuals of each species per bottle) and the cell wells were used to culture individuals separately. These vessels were filled with filtered seawater $(\mathrm{GF} / \mathrm{C})$. About half the volume of seawater in each vessel was exchanged every week, and fecal pellets were also removed. Duration of each developmental stage (nauplius and coepodid) was determined based on daily observations in both sample bottles and cell wells. In particular, for the observations using sample bottles, all nauplii hatched from the same clutch were transferred to one bottle and the stage durations were estimated as the minimum days until the first individuals of copepodid (CI) or adult females and males were observed in the bottles. However, it was impossible to follow each individual in a bottle, especially since metamorphosis from nauplii to copepodids did not occur on the same day even in a population from the same clutch. Therefore, the average of durations from hatching to adult female or male stages were used for the "duration of hatch to adult" calculation. Sediments (primarily of sand and some gravel) and the macroalgae $C$. sinuosa, which were collected together during sampling at St. M, were used as feed. The sediment was washed using a $1 \mathrm{~mm}$ sieve to remove large animals. To kill meiobenthic animals and reduce microbial activity, the sieved sediment was frozen in a deep freezer $\left(-60^{\circ} \mathrm{C}\right)$ for 48 hours and subsequently thawed at room temperature for 24 hours. After this process was repeated 3 times, the sediment was preserved in a freezer. The frozen sediment was thawed in room temperature again destined for copepod food, and was poured into the incubation vessels to $3-5 \mathrm{~mm}$ depth. These sediments were not changed during the incubation experiments. To remove attached microalgae and animals on the surface of $C$. sinuosa, fronds of the algae were washed and cleaned by a toothbrush in filtered seawater and rinsed with distilled water. Until use as food for the copepods, the 
fronds were preserved in a solution of PESI medium (Tatewaki 1966) in an incubator. Each frond was cut into small pieces (ca. $15 \times 15 \mathrm{~mm}$ ) for the cell-well incubation, and two or three fronds, depending on the relative sizes of fronds and sample bottles ( 1 or $2 L$ ), were used for the sample bottle incubation. For the cell-well incubation, a new piece of frond was added when the copepods had consumed a whole piece.

\section{Field investigation on macrophytes and epifauna}

To reveal summer and autumn habitats of $A$. rufocincta and E. spectabilis, samplings for macroalgae and seagrasses in subtidal and intertidal areas were conducted from July to August 2003 at the same beach at the seasonal sampling sites, Ezura Harbor and Hatake Island (Fig. 2). Macrophytes were collected by skin diving. Plastic bags were used for the samplings, and both algae (or seagrass) and surrounding seawater were collected together to avoid the escape of epifauna.

\section{Results}

\section{Environmental parameters}

Over the study period, the mean light quantum in the water column varied both seasonally and with the weather conditions during each sampling month at St. M (Fig. 3A). The highest mean light quantum value was $549.7 \pm$ $745.4 \mu \mathrm{mol} \mathrm{m}^{-2} \mathrm{~s}^{-1}$ in May 1999 when the sky was clear, whereas the lowest of $109.7 \pm 216.2 \mu \mathrm{mol} \mathrm{m}^{-2} \mathrm{~s}^{-1}$ was recorded in December 1999 due to cloudy weather. The mean temperature was the lowest $\left(14.9 \pm 0.3^{\circ} \mathrm{C}\right)$ in March 1999 and the highest $\left(28.0 \pm 0.1^{\circ} \mathrm{C}\right)$ in August 1999 (Fig. $3 \mathrm{~B})$. The mean salinity fluctuated between $32.4 \pm 2.9$ in July 1999 and $34.9 \pm 0.2$ in January 2000 (Fig. 3C). Particularly in the surface layer, salinity decreased due to rainfall on the day before the samplings in April and July 1999, and a passing rain at midnight during the sampling on August 1999. The mean DO increased slightly from August 1999 $\left(5.1 \pm 0.4 \mathrm{~g} \mathrm{~L}^{-1}\right)$ to January $2000\left(8.4 \pm 0.2 \mathrm{~g} \mathrm{~L}^{-1}\right)$ (Fig. 3D) and anoxic conditions were not observed at any time during the sampling period. The seasonal change in mean chl. a concentration showed two peaks (Fig. 3E). The first and highest concetration was $9.3 \pm 6.3 \mu \mathrm{g} \mathrm{L}^{-1}$ in July 1999 , after the rainy season ended. The second peak occurred in September $1999\left(5.49 \pm 4.15 \mu \mathrm{g} \mathrm{L}^{-1}\right)$.

\section{Seasonal occurrence and DVM}

In the seasonal samplings, copepodids of Ambunguipes rufocincta and Eudactylops spectabilis were collected duirng the period of March to May 1999 and December 1999 to January 2000 (Fig. 4). Seasonal occurrences differed between the adults of the two species; A. rufocincta was collected in March, April, May 1999 and January 2000, whereas E. spectabilis was collected in April 1999

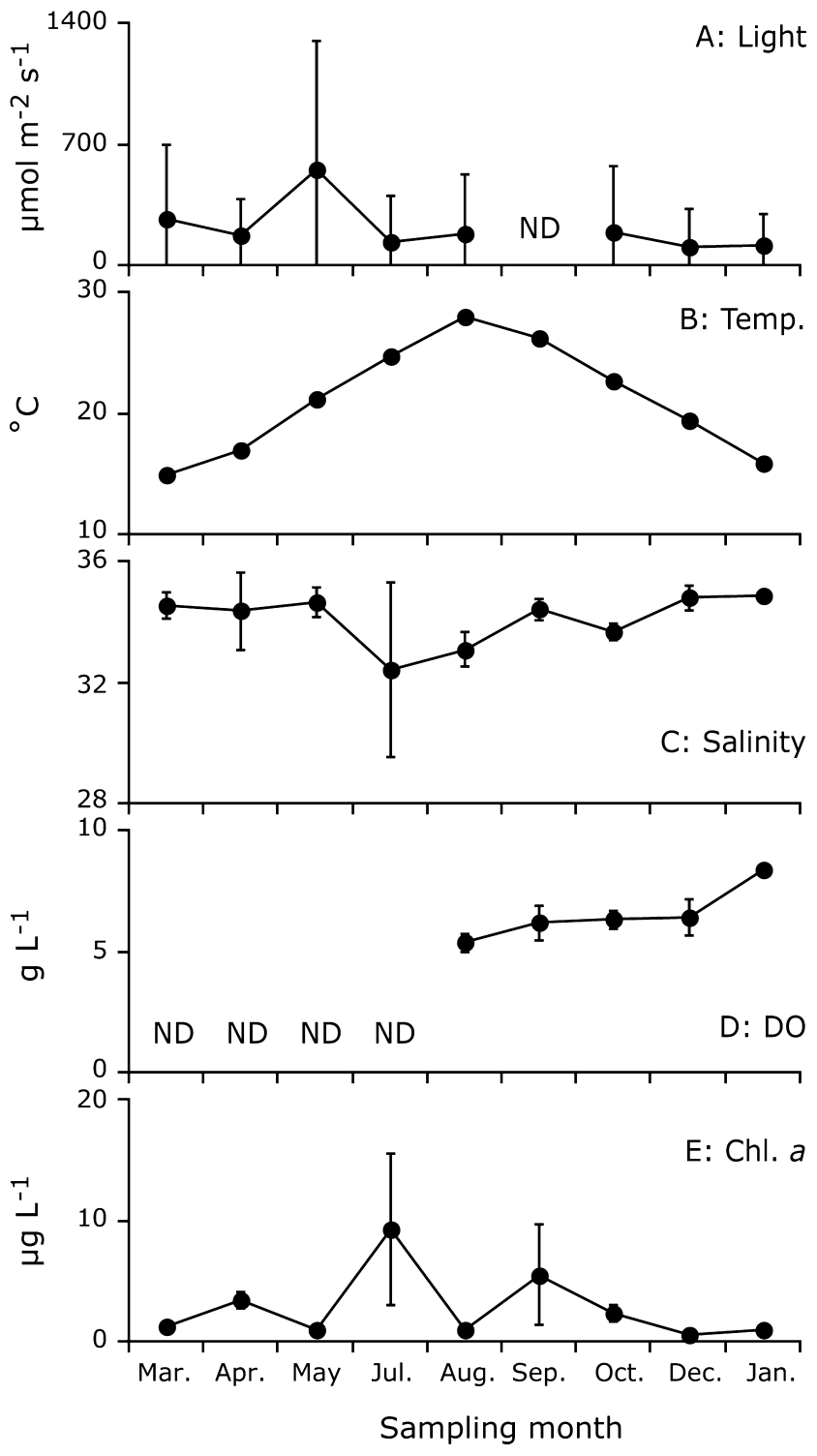

Fig. 3. Seasonal changes of light quantum (A), temperature (B), salinity (C), DO (D), and chl. $a$ (E) at St. M from March 1999 to January 2000. Error bars indicate standard deviation. ND: no data.

and January 2000. The maximum average abundance of $A$. rufocincta (sum of adults and copepodids) was $32.9 \pm 59.7$ individuals $\mathrm{m}^{-3}$ observed in April 1999. In contrast, the average abundance of E. spectabilis (sum of adults and copepodids) was highest in January 2000 (4.8 \pm 6.7 individuals $\mathrm{m}^{-3}$ ). Their abundances during night time sampling were either higher than during the day (Mann-Whitney U-test, $p<0.05$ ), or individuals of the two species appeared in the water column only at night. At night, the individuals of these species were collected only from the surface layers, although some individuals were collected from the nearbottom layers in daytime (Figs. 5 to 7). Throughout the sampling period, the mean WMD of each species at night was shallower than during the day, and the two species were the dominant species in the sledge net samples at this sta- 


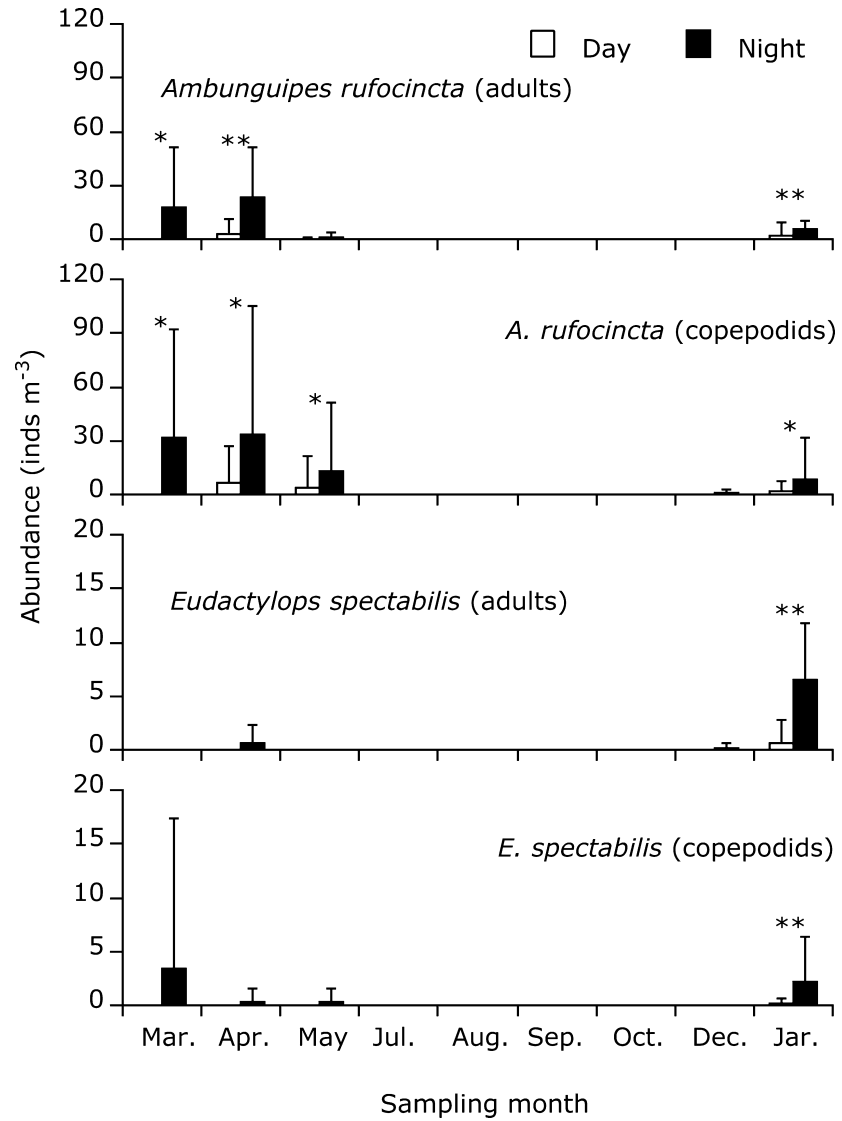

Fig. 4. Seasonal and day/night changes in mean abundances of Ambunguipes rufocincta and Eudactylops spectabilis at St. M from March 1999 to January 2000. Error bars indicate standard deviation. *: $p<0.05,{ }^{* *}: p<0.01$ (Mann-Whitney U-test).

tion (details of the results are shown in Shimode \& Shirayama (2004)). Although the DVM patterns of each species were similar between adult females and males, the sex ratios (\% of males) of adult individuals varied slightly between months (Table 1). The ratios for $A$. rufocincta were around $50 \%$ during both day and night, with the exception of a value of $25 \%$ (only females at night) in May 1999. In contrast, only females of E. spectabilis were collected in April 1999 and the sex ratio was $18 \%$ (12\% in night) in January 2000.

The correlation analysis revealed that significant negative relationships existed between abundance and light quantum for E. spectabilis in January 2000 and for A. rufocincta in March, April, May 1999 and January 2000 (Table 2). Significant negative correlation coefficients were also found between copepodid abundance of $A$. rufocincta and temperature in May 1999 and between copepodid abundance of $E$. spectabilis and DO in January 2000. In contrast, the relationship between Chl. $a$ and copepodid abundance of $E$. spectabilis in January 2000 was significantly positive (Table 2).
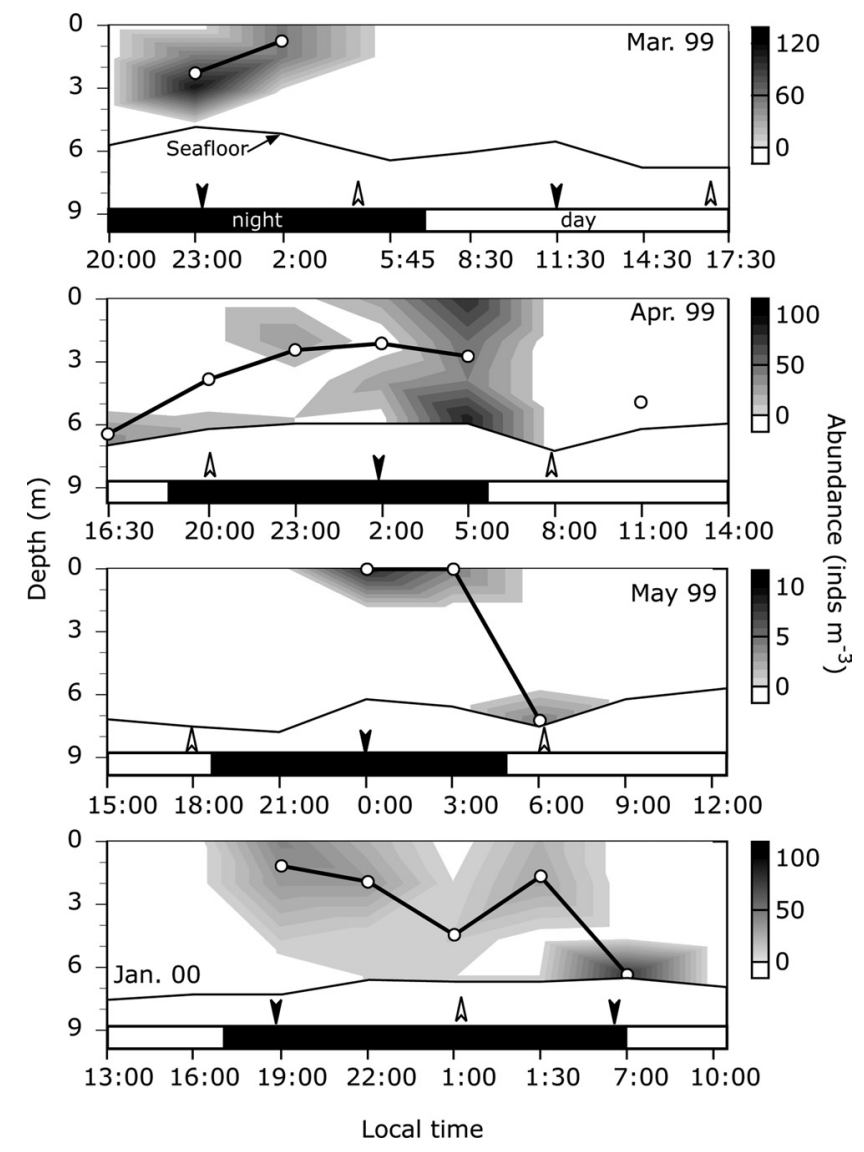

Fig. 5. Diel vertical migration of Ambungipes rufocincta (adults) at St. M in March, April and May 1999, and January 2000. Black lines on each graph indicate weighted mean depths (WMDs). Closed arrowhead: low tide, open arrowhead: high tide.

\section{Generation time and observation}

The mean generation times of $A$. rufocincta and $E$. spectabilis are shown in Table 3. Ambunguipes rufocincta (both in cell wells and in sample bottles) grew faster ( $t$-test: $p<0.05)$ than $E$. spectabilis based on the mean day duration from hatching to adult when incubated at $16^{\circ} \mathrm{C}$. The different numbers of observations between $A$. rufocincta and $E$. spectabilis were related to difficulties in the incubation of the latter species in the laboratory. Ambunguipes rufocincta could be grown to adults in the incubation of both sample bottles and cell wells. The generation times of $A$. rufocincta in the sample bottles and cell wells were almost identical; namely $23.0 \pm 0.8$ days $(\mathrm{n}=4)$ in the bottles and $24.3 \pm 2.8$ days $(\mathrm{n}=26)$ in the cell wells. On the other hand, $E$. spectabilis was unable to grow to the adult stages in the cell wells. They stopped development in the early copepodid stages. They successfully grew to adults only when incubated in the 2- $L$ sample bottles. Therefore, for $E$. spectabilis, we could not examine the duration time of each copepodid stage for either sex.

The duration of the naupliar stages was longer ( $t$-test: $p<0.0001$ ) in E. spectabilis than A. rufocincta (both in cell 

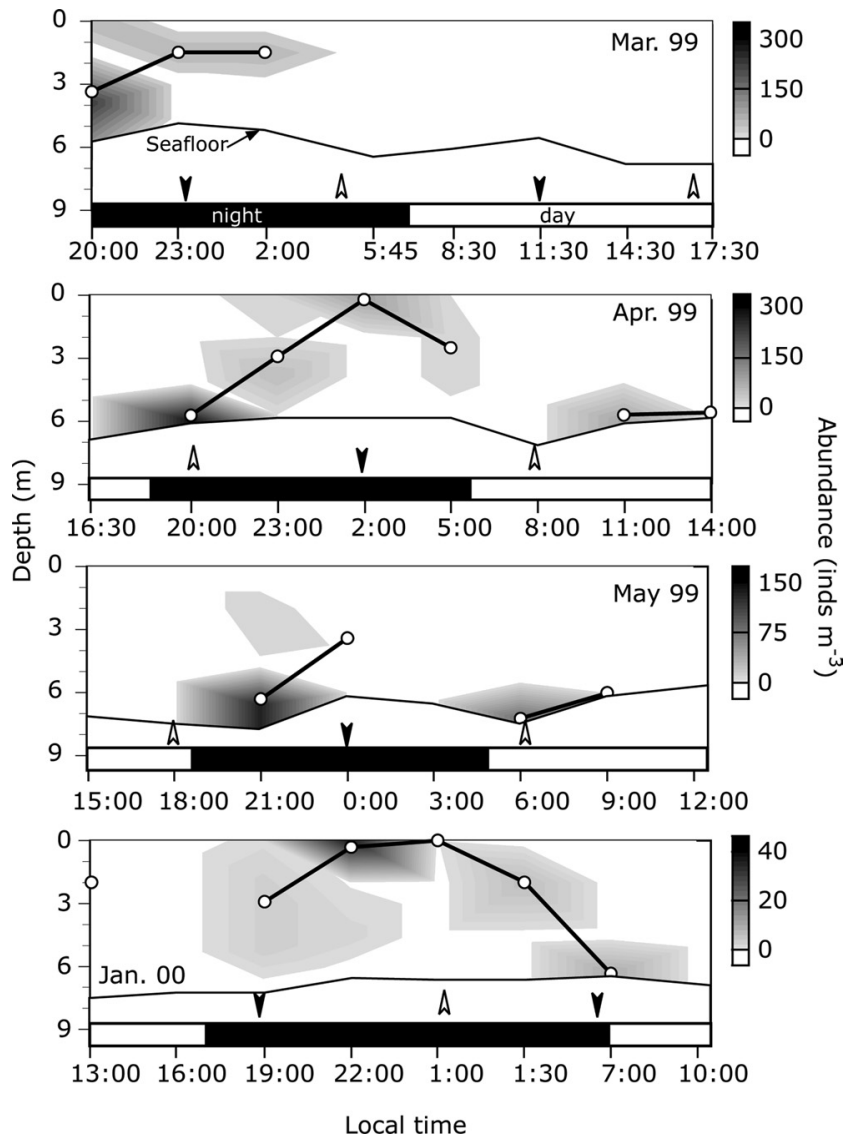

Fig. 6. Diel vertical migration of Ambungipes rufocincta (copepodids) at St. M in March, April and May 1999, and January 2000. Black lines on each graph indicate weighted mean depths (WMDs). Closed arrowhead: low tide, open arrowhead: high tide.

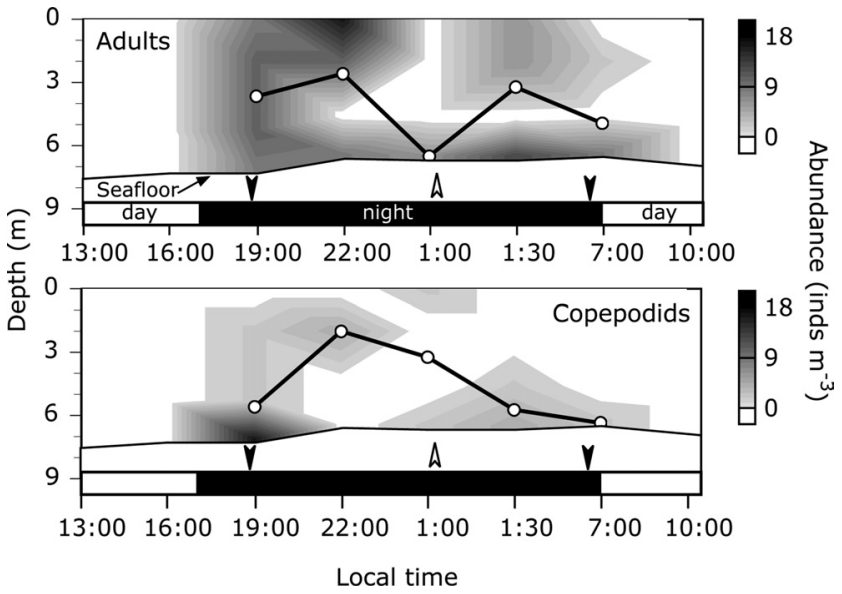

Fig. 7. Diel vertical migration of Eudactylops spectabilis at St. M in January 2000. Black lines on each graph indicate weighted mean depths (WMDs). Closed arrowhead: low tide, open arrowhead: high tide.

Table 1. Sex ratios (\% of males) of adult individuals of Ambunguipes rufocincta and Eudactylops spectabilis in the water column at St. M. Numbers in parentheses indicate the ratios in night samples.

\begin{tabular}{cll}
\hline Species & Sampling Month & $\begin{array}{c}\text { Sex Ratio } \\
(\%)\end{array}$ \\
\hline Ambunguipes rufocincta & March, 1999 & $60(60)$ \\
& April, 1999 & $48(56)$ \\
& May, 1999 & $25(0)$ \\
& January, 2000 & $55(56)$ \\
Eudactylops spectabilis & April, 199 & $90(0)$ \\
& January, 2000 & $18(12)$ \\
\hline
\end{tabular}

Table 2. Correlation coefficients of Spearman's rank test between environmental factors and abundances (ind. $\mathrm{m}^{-3}$ ) of Ambunguipes rufocincta and Eudactylops spectabilis at St. M. Bold: $0.01 \leq p<0.05$, underline+Bold: $p<0.01$. "C" indicates copepodids.

\begin{tabular}{|c|c|c|c|c|c|c|}
\hline Species and stages & Sampling Month & Salinity & Temp. & Light & DO & Chl. $a$ \\
\hline \multirow[t]{4}{*}{ Ambunguipes rufocincta } & March, 1999 & 0.32 & 0.09 & -0.34 & - & -0.14 \\
\hline & April, 1999 & -0.18 & -0.06 & -0.65 & - & 0.15 \\
\hline & May, 1999 & -0.21 & -0.03 & $\overline{-0.22}$ & - & 0.19 \\
\hline & January, 2000 & -0.27 & 0.19 & -0.63 & -0.38 & 0.21 \\
\hline \multirow{5}{*}{ A. rufocincta $C$} & March, 1999 & -0.12 & 0.32 & -0.39 & - & -0.25 \\
\hline & April, 1999 & -0.30 & 0.03 & -0.57 & - & 0.09 \\
\hline & May, 1999 & -0.21 & -0.38 & $\overline{-0.37}$ & - & 0.01 \\
\hline & December, 1999 & -0.19 & -0.14 & -0.28 & -0.03 & -0.25 \\
\hline & January, 2000 & 0.18 & -0.11 & -0.43 & 0.10 & -0.11 \\
\hline \multirow[t]{3}{*}{ Eudactylops spectabilis } & April, 1999 & -0.12 & -0.09 & -0.24 & - & -0.01 \\
\hline & December, 1999 & 0.29 & -0.03 & -0.13 & 0.10 & 0.17 \\
\hline & January, 2000 & -0.16 & 0.11 & -0.51 & -0.16 & 0.28 \\
\hline \multirow[t]{4}{*}{ E. spectabilis $\mathrm{C}$} & March, 1999 & 0.01 & -0.01 & -0.16 & - & 0.25 \\
\hline & April, 1999 & -0.26 & -0.09 & -0.17 & - & 0.24 \\
\hline & May, 1999 & -0.15 & -0.09 & -0.20 & - & 0.24 \\
\hline & January, 2000 & 0.04 & 0.21 & -0.80 & -0.51 & 0.46 \\
\hline
\end{tabular}


Table 3. Comparison of stage duration time (days \pm SD) for Ambunguipes rufocincta and Eudactylops spectabilis. The results for A. rufocincta are based on the incubations using sample bottles and cell wells. Those of E. spectabilis were estimated from observations on the sample bottle incubations.

\begin{tabular}{|c|c|c|c|c|}
\hline \multirow{2}{*}{ Stages } & \multicolumn{3}{|c|}{ Ambunguipes rufocincta } & \multirow{2}{*}{$\begin{array}{c}\text { Eudactylops spectabilis } \\
\text { Sample bottle }\end{array}$} \\
\hline & \multicolumn{2}{|c|}{ Cell well } & Sample bottle & \\
\hline Egg & $3.9 \pm 1.2$ & $\mathrm{n}=14$ & Not determined & Not determined \\
\hline Nauplius & $7.5 \pm 1.1$ & $\mathrm{n}=40$ & $8.0 \pm 0.8 \quad n=4$ & $13.3 \pm 1.03 \mathrm{n}=6$ \\
\hline Copepodid (CI to adult) & $16.8 \pm 2.4$ & $\mathrm{n}=26$ & Not determined & Not determined \\
\hline female (CI to adult) & $18.3 \pm 1.7$ & $\mathrm{n}=14$ & Not determined & Not determined \\
\hline male (CI to adult) & $15.0 \pm 1.8$ & $\mathrm{n}=12$ & Not determined & Not determined \\
\hline Hatch to Adult & $24.3 \pm 2.8$ & $\mathrm{n}=26$ & $23.0 \pm 0.8 \quad n=4$ & $27.0 \pm 4.1 \quad n=6$ \\
\hline
\end{tabular}

wells and in sample bottles). In A. rufocincta, the duration time of the nauplius stage was shorter than that of the copepodid stages $(t$-test: $p<0.0001)$. A significant difference $(t$ test: $p=0.002$ ) was also observed in the duration time of copepodid stages between females $(18.3 \pm 1.7$ days $)$ and males ( $15.0 \pm 1.8$ days) for A. rufocincta. Although there were no observations of the duration times of copepodids between females and males of E. spectabilis, we frequently found the male individuals earlier than the females in the same incubation bottle (from the same egg sac).

In additon to the difference of incubation vessels, $A$. rufocincta was able to develop into adults when they were incubated with Colpomenia sinuosa. In contrast, E. spectabilis was unable to develop into adults when incubated only with $C$. sinuosa. They successfully grew to adults when incubated with both $C$. sinuosa and the sediments. During the incubation, a reduction of algal amount and fecal pellet production were observed in A. rufocincta, and feeding behaviors on both algae and sediments were observed in E. spectabilis.

\section{Dry weight and carbon and nitrogen contents}

Both A. rufocincta and E. spectabilis exhibited highly significant correlations between body length and dry, carbon and nitrogen weights (Fig. 8). Both adult female and male individuals of $A$. rufocincta were larger than those of E. spectabilis in terms of both body length and dry weight ( $t$-test: $p<0.05$, Table 4). Carbon and nitrogen contents and carbon/nitrogen $(\mathrm{C} / \mathrm{N})$ ratios of the adults are also shown in Table 4. The nitrogen content of E. spectabilis was higher than that of $A$. rufocincta ( $t$-test: $p=0.0013$ ), whereas the carbon contents of these species were almost identical. Because the difference in the nitrogen contents was responsible for the differences in $\mathrm{C} / \mathrm{N}$ ratios of each species, $A$. rufocincta exhibited a higher $\mathrm{C} / \mathrm{N}$ ratio than $E$. spectabilis ( $t$ test: $p=0.0002$ ).

\section{Field investigation on macrophytes and epifauna}

We collected several macrophytes including Chloro-

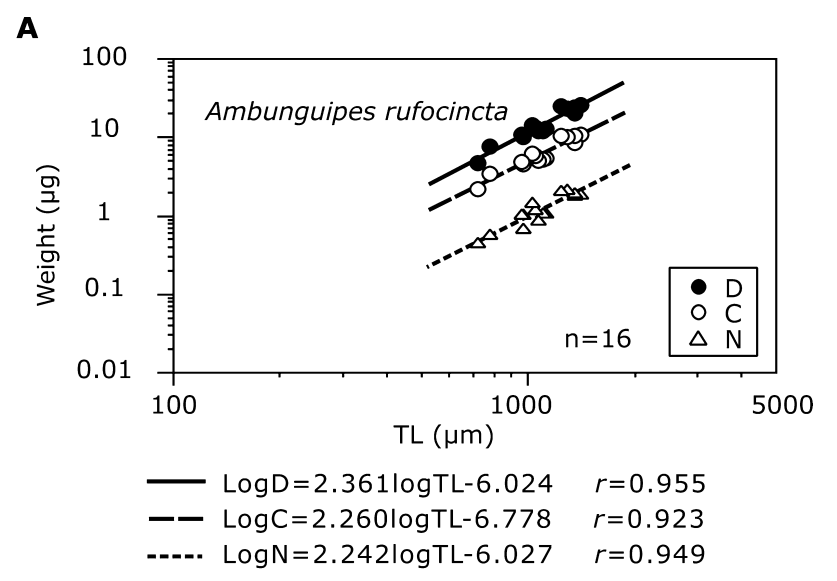

B

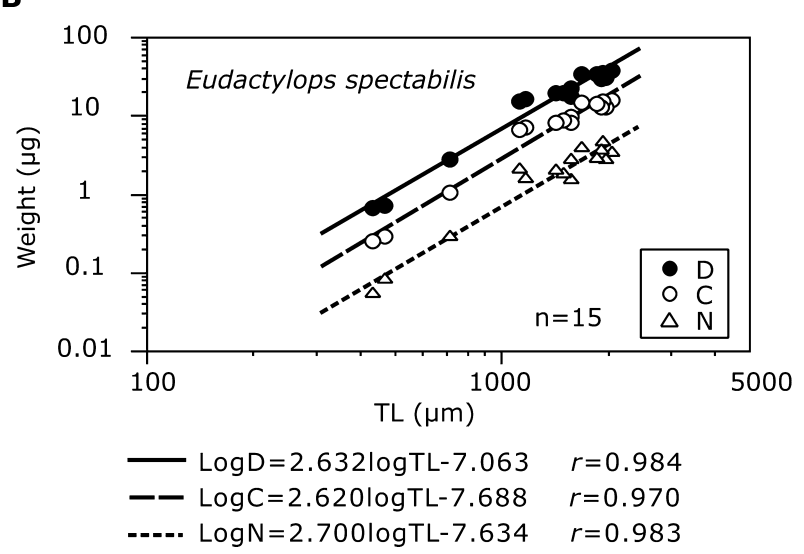

Fig. 8. Relationship between body-weight and -length of Ambunguipes rufocincta (A) and Eudactylops spectabilis (B). D: dry weight, C: carbon weight, $\mathrm{N}$ : nitrogen weight.

phytes (Ulva spp.), Phaeophytes (Dictyota spp., Sargassum spp., Zonaria spp., etc.), Rhodophytes (Peyssonnelia spp., Porphyra spp., etc.) and seagrasses (Zostera spp. and Halophila ovalis). Among these macrophytes, a few adults and copepodids of $A$. rufocincta were found only from small patches of $H$. ovalis at the beach of the seasonal sampling site in an area shallower (ca. $4 \mathrm{~m}$ in depth) than at St. $\mathrm{M}$, and in the subtidal zones of a sandy beach on Hatake Is- 
Table 4. Comparison of body length, weight and chemical composition of adult individuals of Ambunguipes rufocincta and Eudactylops spectabilis. *: $0.01 \leq p<0.05, * *: p<0.01$ ( $t$-test).

Ambunguipes rufocincta

$\begin{array}{rl}1.21 \pm 0.20 & \mathrm{n}=58 \\ 1.03 \pm 0.08 & \mathrm{n}=103 \\ & \\ 23.79 \pm 2.17 & \mathrm{n}=5 \\ 12.45 \pm 1.19 & \mathrm{n}=6 \\ 43.25 \pm 1.31 & \mathrm{n}=16 \\ 8.75 \pm 1.05 & \mathrm{n}=16 \\ 5.00 \pm 0.60 & \mathrm{n}=16\end{array}$

Eudactylops spectabilis

$$
\begin{array}{rl}
1.89 \pm 0.13 & \mathrm{n}=48 \\
1.45 \pm 0.13 & \mathrm{n}=103 \\
33.78 \pm 2.26 & \mathrm{n}=6 \\
14.28 \pm 1.24 & \mathrm{n}=5 \\
42.27 \pm 2.07 & \mathrm{n}=15 \\
10.92 \pm 1.84 & \mathrm{n}=15 \\
3.95 \pm 0.66 & \mathrm{n}=15
\end{array}
$$

land (Fig. 2). During the short-term observation in the laboratory, their feeding behaviors on $H$. ovalis were observed, and this was identical to that on $C$. sinuosa.

\section{Discussion}

Our result from the field investigation showed that Ambunguipes rufocincta and Eudactylops spectabilis at St. M swam up to the surface layer during the night and returned to the near-bottom layers before sunrise. This observation was supported by the Spearman's rank correlation analysis, which revealed that significant negative relationships existed between their abundance and light quantum. This result indicates that their diel vertical migration (DVM) was affected by diel changes in ambient light. Several authors have suggested that diel changes in ambient light intensity are the prime environmental factor controlling DVM of copepods, which are considered to gain an adaptive advantage through avoidance of visual predatory fishes (Mauchline 1998). Various fish species inhabit nearshore shallow waters, which are also important as "nursery grounds" for the larvae and juveniles of other fishes (Blaber and Blaber 1980). These fishes are potential predators of copepods occurring in the water column (Schafer et al. 2002). At our sampling site, we frequently observed such fishes (e.g., Spratelloides spp., Girella spp. Acanthopagrus spp., etc.) during skin diving for the macrophyte sampling. Therefore, our result suggest that the DVM of A. rufocincta and E. spectabilis could reduce the risk of attack by visual predators in the water column.

On the other hand, vertical migrations of some copepods in nearshore shallow waters, particularly in estuaries where strong tidal currents exist, have been shown to be controlled by tidal cycles (Schlacher \& Wooldridge 1995). In our study site, the tidal currents would be relatively weak compared with the above study sites, because our site was not in an estuary system. In fact, the mean WMDs of most coepepod species, including $A$. rufocincta and E. spectabilis, were not statistically different among four tidal phases, i.e, high tide, high to low tide, low tide and low to high tide (Shimode \& Shirayama 2004). In addition, the risk that $A$. rufocincta and E. spectabilis would be carried away from suitable algal habitats by tides is not high, since algal mats of Colpomenia sinuosa were commonly observed at other beaches in the bay (e.g, Ezura Harbor, Hatake Island, etc.) during every winter to spring period.

During nighttime, both adults and copepodids of $A$. rufocincta and E. spectabilis performed DVM. Egg-bearing adult females were also collected in the water column, implying that the DVMs of the two species were probably not related to mating behavior. The sex ratios of $A$. rufocincta in the water column were almost the same (ca. 50-60\%) during all sampling periods except for May 1999. These results indicate that besides the copepodids, both adult males and adult females of $A$. rufocincta performed DVM. In contrast, DVM in E. spectabilis was performed mainly by adult females and copepodids, because the sex ratios were $>20 \%$ or $0 \%$. In a previous paper (Shimode \& Shirayama, 2004), we reported that $A$. rufocincta and E. spectabilis dominated in the algal habitat of $C$. sinuosa at the sampling site, based on sledge net samplings in January 2000. In the daytime sample by sledge net, the sex ratios of $A$. rufocincta and $E$. spectabilis were $60 \%$ and $63 \%$, respectively. If these ratios were consistent within the algal habitat during this season, this would strongly support the above interpretation that male of E. spectabilis do not undertake DVM. However, sex ratios of some harpacticoids have been known to vary depending on season (Hicks \& Coull 1983), which might have caused the decrease in the sex ratio of $A$. rufocincta in May 1999. Therefore, further studies on the sex ratios of these species in and around their algal habitat are required.

In the laboratory observations, these copepods successfully grew to adults based on only $C$. sinuosa (and/or sediment) as their food. This indicates that feeding in the water column is not a dietary prerequisite. We also observed that their nauplii were poor swimmers, tightly grasping fronds of the algae. Therefore, we expect their dispersal ability is low during the naupliar stages. Several authors have suggested that meiobenthic harpacticoids emerge into the water column during nighttime to aid in dispersal, while avoiding predation by pelagic fish (and/or benthic predators) (Walters 1988b, Bell et al. 1989, Kurdziel \& Bell 
1992, Walters \& Bell 1994). The dispersal by some such species has been known to be "density-dependent" (Service \& Bell 1987, Walters 1991). In the present study, our laboratory observations suggest that inbreeding in A. rufocincta might reduce both the clutch size and hatching success (Shimode \& Shirayama, unpublished data). Additionally, intra- and inter-specific competition for food was less likely to exist among $A$. rufocincta and E. spectabilis during the middle periods (i.e. January to April) of their occurrence, because $C$. sinuosa was so abundant around the sampling station. In conclusion, after the individuals of the species grow to stages capable of strong swimming, they are considered to perform night emergence behavior to aid in density-dependent dispersal to avoid the risk of inbreeding depression rather than to avoid intra- and inter-specific competition for food.

Hicks \& Coull (1983) suggested that rapid growth in males is related to precocious coupling behavior. In this study, precocious coupling of $A$. rufocincta and $E$. spectabilis were observed frequently during our incubations. Therefore, in the two species, faster growth of the males is probably an adaptation to grasp immature females faster than other individuals. The egg duration of $E$. spectabilis was not determined in this study. However, if it is almost the same (ca. 4 days) as in A. rufocincta, the generation times, including egg stage duration, would be ca. 30 days in both species. These generation times are similar to that of Acartia steueri $\left(31.1\right.$ days at $16.8^{\circ} \mathrm{C}$ reported by Uye, (1981)) that appeared simultaneously with $A$. rufocincta and E. spectabilis at St. M (Shimode \& Shirayama 2004).

The carbon contents were not significantly different between A. rufocincta and E. spectabilis and their values agreed with those of the copepod species from the Inland Sea of Japan reported by Uye (1982). Although the nitrogen content of E. spectabilis was also identical to those from the Inland Sea, the content of $A$. rufocincta was lower than that of E. spectabilis. Consequently, the $\mathrm{C} / \mathrm{N}$ ratio of $A$. rufocincta was higher than that of E. spectabilis. The $\mathrm{C} / \mathrm{N}$ ratio is known to be an index of the fat/protein content in animal bodies (Ikeda 1974). The chemical difference between the two species is most probably attributable to the difference in their food items. Our laboratory incubation indicated that $A$. rufocincta was able to grow to the adult stage when incubated with $C$. sinuosa, while $E$. spectabilis required both $C$. sinuosa and sediments. In fact, direct feeding on the algal fronds (reduction of algal amount and fecal pellet production) by $A$. rufocincta was observed throughout the incubation, whereas $E$. spectabilis seemed to eat the mucus-like structure on the surface of $C$. sinuosa rather than the fronds themselves. As for other epifauna of macrophytes, including harpactiocoids, most species are known to feed on attached detritus and/or microalgae, and direct grazing of the macrophytes is rare except for in some amphipods and snails (Mukai 1994). The feeding behavior of E. spectabilis observed in the laboratory implies that the field population of the species could utilize detritus and attached microalgae on the algal surfaces as food. On the other hand, A. rufocincta could also feed on C. sinuosa together with detritus and attached microalgae in the field, because they were able to consume whole fronds of the algae. However, the importance of detritus and microalgae as food might be low for them (particually A. rufocincta), because they were not abundant on the algal surface of $C$. sinuosa collected by the sledge net samplings. Additionally, A. rufocincta and E. spectabilis successfully grew to adult stages in our incubation using cleaned fronds of $C$. sinuosa without detritus and attached microalgae. Our result implies that the main food of $A$. rufocincta was the fronds of $C$. sinuosa, whereas $E$. spectabilis utilized both the algae and sediments as food. Because the food quality of sediments is generally low (Valiela 1995), E. spectabilis probably was unable to store as much fat within their bodies to the extent of $\mathrm{A}$. rufocincta. In the field sampling, the abundances of $\mathrm{A}$. rufocincta were much higher in both the water column (Fig. 4) and the macroalgal habitat (Shimode \& Shirayama 2004) than those of E. spectabilis. These results suggest that $A$. rufocincta probably had an advantage in that direct ingestion of the macroalgae may have led to higher fat contents and high reproduction rate. In fact, although both species produced one egg sac containing ca. 30-40 eggs, the intervals after hatching until producing a new egg sac were usually shorter in A. rufocincta (>1-3 days) than E. spectabilis (more than 2 days) (Shimode \& Shirayama, unpublished data).

In the seasonal sampling, A. rufocincta and E. spectabilis appeared simultaneously with growth of $C$. sinuosa in the winter and were not collected from the water column at St. $M$ after early summer when the algae was withered. In the laboratory, the two harpacticoids were able to survive at higher temperatures than $16^{\circ} \mathrm{C}$, although the algae decayed at high temperatures $\left(>20^{\circ} \mathrm{C}\right)$. This indicates that their seasonal occurrences at the study site are probably limited by the food rather than high temperatures. Their seasonal occurrence seemed to follow the pattern of the previous studies that report "synchronous occurrence" of the animals inhabiting macrophytal habitats (Mukai 1971, 1996). However, it is still unclear how these animals survive during the absence of seagrass or algae (Mukai 1996). In the later field samplings for macrophytal communities during summer 2003, A. rufocincta were found on the seagrass, Halophila ovalis, in an area shallower than St. M, and this could be a refuge population to enable them to survive the period without $C$. sinuosa. In addition, laboratory observations suggest that $A$. rufocincta used the seagrass for habitat and food as in the case of $C$. sinuosa. However, E. spectabilis was not collected in the later field surveys during summer and autumn, including the samplings in 2003. These results indicate that $A$. rufocincta probably sustains its population by moving to different habitats though the DVM behavior and changing food items from $C$. sinuosa to $H$. ovalis during summer (Fig. 9). Therefore, at least for A. rufocincta, 


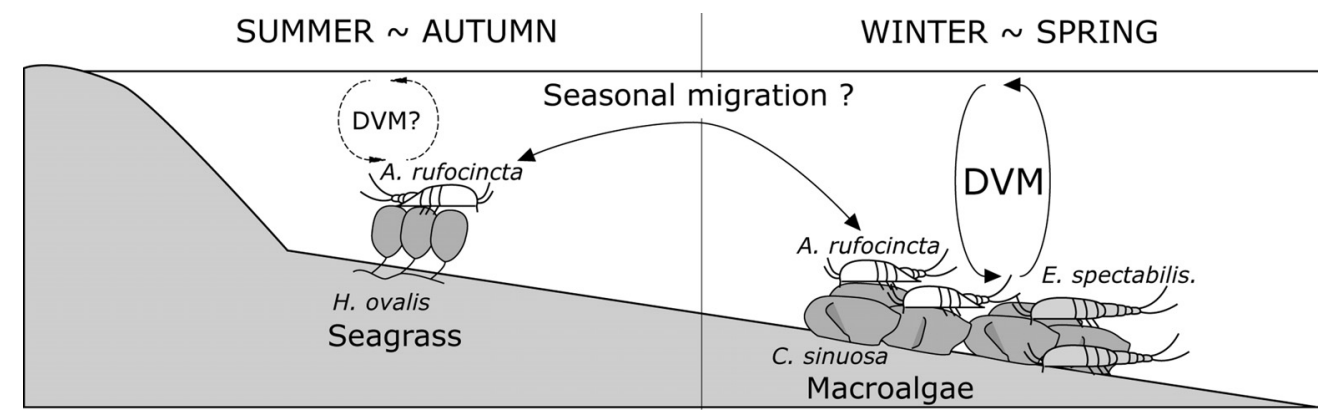

Fig. 9. A schematic diagram of the life strategies of Ambunguipes rufocincta and Eudactylops spectabilis.

the DVM behavior might be indispensable in their life strategy for sustaining their populations year round.

\section{Acknowledgements}

We express sincere thanks to Dr. K. Takahashi and Mr. H. Takatsuji for skilful technical advice on the elemental analysis, and to Prof. H. Ogawa, Dr. H. Kawai and Mr. T. Shimono for technical advice on algal incubation. We are thankful to Captain Y. Yamamoto and Mr. K. Okita of T/RV Janthina III of Seto Marine Biological Laboratory, Kyoto University for their help in the flied samplings. Thanks are also due to Dr. T. C. Shirley for kindly helping to improve the English text and for valuable comments. Dr. N. Iwasaki, Dr. T. Kikuchi, Dr. S. Nishida and Dr. T. Toda provided helpful comments on an earlier version of this manuscript. This manuscript was improved by the valuable comments of the editor and two anonymous reviewers to whom we are indebted. This study was partially supported by a research grant from the Japan Ministry of Education, Science, Sports and Culture (Nos. 11440154) and from the 21st century centers of excellence program "Environmental Risk Management for Bio/Eco-Systems" of Yokohama National University.

\section{Literature Cited}

Armonies W (1988) Active emergence of meiofauna from intertidal sediment. Mar Ecol Prog Ser 43: 151-159.

Armonies W (1989) Meiofaunal emergence from intertidal sediment measured in the field-significant contribution to nocturnal planktonic biomass in shallow waters. Helgol Meeresunters 43: $29-43$.

Armonies W (1990) Short-term changes of meiofaunal abundance in intertidal sediments. Helgol Meeresunters 44: 375-386.

Armonies W (1994) Drifting meiobenthic and macrobenthic invertebrates on tidal flats in Konigshafen-a Review. Helgol Meeresunters 48: 299-320.

Bell SS, Hicks GRF, Walters K (1989) Experimental investigations of benthic reentry by migrating meiobenthic copepods. J Exp Mar Biol Ecol 130: 291-303.

Blaber SJM, Blaber TG (1980) Factors affecting the distribution of juvenile estuarine and inshore fish. J Fish Biol 17: 143-162.
Brady GS (1880) A monograph of the free and semi-parasitic Copepoda of the British Islands, 2. The Ray Society, London.

Brian A (1923) Elenco di copepodi marini bentonici proveniente da Rovigno e descrizione du una $\mathrm{n}$. varieta di Parathalestris clausi Norm. Monit Zool Ital 34: 126-135.

Chang CY, Song SJ (1995) Marine harpacticoid copepods of genus Eudactylopus (Harpacticoida, Thalestridae) in Korea. Korean J Syst Zool 11: 379-388.

Frost BW, Bollens SM (1992) Variability of diel vertical migration in the marine planktonic copepod Pseudocalanus newmani in relation to its predators. Can J Fish Aquat Sci 49: 1137-1141.

Hicks GRF, Coull BC (1983) The ecology of marine meiobenthic harpacticoid copepods. Oceanogr Mar Biol Ann Rev 21: 67175.

Ikeda K (1974) Nutritional ecology of marine zooplankton. Mem Fac Fish Hokkaido Univ 22: 1-97.

Kurdziel JP, Bell SS (1992) Emergence and dispersal of phytaldwelling meiobenthic copepods. J Exp Mar Biol Ecol 163: 4364.

Mauchline J (1998) The biology of calanoid copepods. Adv Mar Biol 33: 1-170.

Mukai H (1971) The phytal animals on the thalli of Sargassum serratifolium in the Sargassum region, with reference to their seasonal fluctuations. Mar Biol 8: 170-182.

Mukai H (1994) Communities in marine macrophytic vegetation-lives on algal thalli or leaves of seagrasses-. Aquabiology 90: 19-22. (In Japanese with English abstract)

Mukai H (1996) Communities in marine macrophytic vegetation-population dynamics of phytal animals-. Aquabiology 102: 44-46. (In Japanese with English abstract)

Schafer LN, Platell ME, Valesini FJ, Potter IC (2002) Comparisons between the influence of habitat type, season and body size on the dietary compositions of fish species in nearshore marine waters. J Exp Mar Biol Ecol 278: 67-92.

Schlacher TA, Wooldridge TH (1995) Small-scale distribution and variability of demersal zooplankton in a shallow, temperate estuary: Tidal and depth effects on species-specific heterogeneity. Cah Biol Mar 36: 211-227.

Service SK, Bell SS (1987). Density-influenced active dispersal of harpacticoid copepods. J Exp Mar Biol Ecol 114: 49-62.

Shimode S, Shirayama Y (2004) Diel changes in vertical distribution of copepods community in Tanabe Bay, Japan. J Mar Biol Assoc UK 84: 607-613.

Song SJ, Yun SG, Chang CY (1999) New records on three harpacticoid copepods associated with marine macroalgae in 
Korea. J Fish Sci Tech 2: 189-198.

Tatewaki M (1966) Formation of a crustaceous sporophyte with unilocular sporangia in Scytosiphon lomentaria. Phycologia 6: $62-66$.

Uye S (1981) Fecundity studies of neritic calanoid copepods Acartia clausi Giesbrecht and A. steueri Smirnov: A simple empirical model of daily egg production. J Exp Mar Biol Ecol 50: $255-271$.

Uye S (1982) Length-weight relationships of important zooplankton from the Inland Sea of Japan. J Oceanogr Soc Japan 38: $149-158$.

Valiela I (1995) Marine ecological processes. Springer-Verlag, New York.

Walters K (1988a) Diel vertical migration of sediment-associated meiofauna in subtropical sand and seagrass habitats. J Exp Mar Biol Ecol 117: 169-186.

Walters K (1988b) Experimental investigations of vertically migrating meiofaunal populations in subtropical sand and seagrass habitats. Diss Abstr Int B Sci Eng 48: 2862.

Walters K (1991) Influences of abundance, behavior, species composition, and ontogenic stage on active emergence of meiobenthic copepods in subtropical habitats. Mar Biol 108: 207-215.

Walters K, Bell SS (1986) Diel patterns of active vertical migration in seagrass meiofauna. Mar Ecol Prog Ser 34: 95-103.

Walters K, Bell SS (1994) Significance of copepod emergence of benthic, pelagic, and phytal linkages in a subtidal seagrass bed. Mar Ecol Prog Ser 108: 237-249. 